\title{
ACERCA DE LA REMISIÓN NORMATIVA EN LA INTERRUPCIÓN CIVIL DE LA PRESCRIPCIÓN EXTINTIVA LABORAL. REFLEXIONES CRÍTICAS
}

\author{
Carlos Ellenberg Oyarce*
}

\begin{abstract}
RESUMEN
El presente estudio pretende demostrar ciertas inconsistencias de que adolece el artículo 510 del Código del Trabajo, traducidas en infracción al principio de la protección que inspira al Derecho Laboral. Específicamente, el autor critica el reenvío ordenado por dicha norma al artículo 2523 del Código Civil en cuanto a la regulación de la interrupción civil de la prescripción liberatoria laboral mediante "requerimiento" y el endurecimiento por la Corte Suprema-en materia laboral- del criterio de determinación del instante en que se produce tal interrupción. Para estos fines el autor expone las posturas existentes sobre el momento interruptivo y se refiere al peligro de trasladar antiguas discusiones civiles al Derecho del Trabajo; desarrolla, a partir de los efectos substantivos de la demanda, aquella posición que estima más tutelar para los derechos del dependiente y propone, de lege ferenda, una solución en la tramitación administrativa ante la Inspección del Trabajo.
\end{abstract}

REQUERIMIENTO - NOTIFICACIÓN - PRINCIPIO PRO OPERARIO

\section{Regarding legal cross-reference to the interruption of liberative prescription (statute of limitations) in labour law. Critical thoughts}

\begin{abstract}
The present study hopes to prove certain inconsistencies in Article 510 of the Chilean Labour Code, that involve the violation of the principle of protection that inspire Labour law. Specifically, the author criticizes the forwarding ordered by said regulation to Article 2423 of the Civil Code, on account of the regulation of civil interruption of statute of limitations by means of a "requirement", and the hardening undertaken by the Supreme Court of the criteria used to determine the instant in which the interruption is carried out. For these purposes, the author exposes the various existing opinions in regard to the moment of interruption, and also refers to the dangers in transferring some long-standing civil discussions towards the Labour Code. Then be explains the standpoint he values as sheltering for the rights of the dependant and suggests a lege ferenda solution to the administrative processing before Labour Inspection.
\end{abstract}

$$
\text { REQUIREMENT - NOTICE - PRO OPERARIO PRINCIPLE OF }
$$

* Abogado, Estudiante del programa de postgrado Diplomado en Derecho Inmobiliario de la Facultad de Ciencias Jurídicas y Sociales de la Universidad Austral de Chile, Valdivia, XIV Región de Los Ríos, Chile. c.ellenberg@gmail.com

Artículo recibido el 28 de agosto de 2009 y aceptado para su publicación por el Comité Editorial el 26 de octubre de 2009. 


\section{INTRODUCCIÓN ${ }^{1}$}

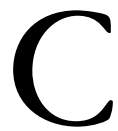

uando hace más de un siglo la ciencia jurídica vio desprenderse del Derecho Civil al entonces denominado Derecho Obrero, poco tardaron los doctrinadores de otras latitudes en explicar que esto se debía a una diferencia axiomática entre ambos derechos. El primero construía toda su base argumentativa en torno a la autonomía de la voluntad y la igualdad de partes, mientras que el segundo requería -por la cuestión social derivada del trabajo- de un sólido cimiento diseñado a partir de la desigualdad de partes y un carácter tutelar del más débil: ${ }^{2}$ el trabajador. El mecanismo establecido para traducir jurídicamente esta desigualdad fue la subordinación y dependencia (económica), y desde ahí la cuestión no ha radicado en discutir este axioma, sino más bien en encontrar la norma más adecuada para consolidarlo. Ello implica un alto desafío para el Estado, toda vez que la problemática del trabajo está teñida de un predominante factor político derivado del fin de este Derecho (protección del trabajador, pacificación social y consolidación del capitalismo moderado), ${ }^{3}$ razón que explica el alto impacto que tiene la consagración, modificación y derogación de su contenido en la sociedad toda. Además, estos valores -en inmediata relación con la teoría de los derechos fundamentales y su eficacia directa- llevaron a una natural constitucionalización al Derecho Laboral.

En nuestro país, la contundente evolución normativa de esta especialidad ha propendido, con mayor o menor felicidad, a equilibrar los fines en juego amén de la prioridad del valor de la protección. Por mencionar un caso, se aplaude la modificación a todo el Derecho Procesal del Trabajo a partir de la Ley No 20.087. Comparemos, por ejemplo, los requisitos de la sentencia definitiva del artículo 170 del CPC y los del artículo 459 del CT. El resultado nos revela una evolución notable: una obligación del juez del grado de manejar razonablemente la teoría iusfundamentalista; superar al juez silogista es un cambio en la forma de entender el derecho. "Un triunfo del individuo frente a la mayoría”, diría Dworkin.

A partir de tales nociones introductorias, el presente artículo pretende estar fundamentado desarrollando las ideas precedentes, pero tiene un objetivo más modesto: demostrar cómo y por qué la institución de la interrupción civil de la prescripción

${ }^{1}$ Abreviaciones más frecuentes que encontrará el lector en este trabajo; CPR: Constitución Política de la República de Chile de 1980; CC: Código Civil chileno; CT: Código del Trabajo chileno; CPC: Código de Procedimiento Civil chileno; CS: Corte Suprema de la República de Chile; RDJ: Revista de Derecho y Jurisprudencia; L\&S: Leyes y Sentencias. Revista de Legislación y Jurisprudencia; Cons.: considerando.

${ }^{2}$ Cuestión de la que el Derecho Laboral se ocupó mucho antes que el Derecho Civil. Para nadie es un misterio que gran parte de los negocios que celebran las personas comunes y corrientes para cubrir necesidades básicas no son compraventas simples de cosa mueble, sino que contratos de adhesión con cláusulas abusivas, que bajo pretexto de criterios de eficiencia y disminución de costos de transacción, devalúan notoriamente la autonomía de la voluntad y sus ramificaciones. Vid. Wahl, J., "Los contratos de adhesión: Normas de equidad en las estipulaciones y en el cumplimiento", en Cuadernos de Extensión Jurídica, Universidad de Los Andes, núm. 12, 2006, pp. 59-62. Otro caso lo encontramos en el Derecho del Consumo, el que si no es parte del Derecho Civil, al menos puede decirse que es un apéndice de él.

${ }^{3}$ Gamonal, S., Fundamentos de derecho laboral, Editorial Legal-Publishing Chile, Santiago, 2008, p. 13 . 
extintiva laboral del artículo 510 del CT, remitiéndose por mandato legal al artículo $2523 \mathrm{~N}^{\circ} 2$ del Código Civil -norma de un contenido históricamente discutido en nuestro medio- ha quedado desmembrada del carácter tutelar de las normas laborales, pasando desapercibida en las baterías modificatorias del CT. Sin perjuicio de referirme tangencialmente a otra preceptiva laboral relativa al paso del tiempo, me avocaré a tal propósito desde el derecho individual del trabajo, tomando como referencia el caso del despido injustificado y utilizando jurisprudencia a mero título ilustrativo para exponer las posturas que existen acerca del instante interruptivo. Además, será un recurso omnipresente en el cuerpo de la investigación el principio de la protección, que sólo enfocaré en las dos vertientes de su subprincipio "pro operario", esto es, la legislativa (criterio pro operario) y la judicial (in dubio pro operario). La estructura del trabajo sugiere además de esta introducción: (I) el tratamiento de la voz requerimiento en las prescripciones civiles de corto tiempo y en materia laboral; (II) diversos argumentos de por qué no resulta adecuada la traslación de viejas discusiones civiles al Derecho del Trabajo, sus consecuencias y una teoría de fijación del momento interruptivo; (III) una propuesta desde lo administrativo, y (IV) conclusiones.

\section{Artículo 510 inciso quinto del Código del Trabajo. Tratamiento de la IrRadiación del Código Civil EN El derecho laboral}

En Chile, tradicionalmente los Códigos del Trabajo han sido una reunión de decenas de leyes refundidas, coordinadas y sistematizadas mediante otro producto normativo de rango legal. Así ha ocurrido desde la instauración del que fuera el primer CT en el año 1931, el CT de 1978, el CT de 1987 y el CT de 1994, el que a la fecha ha resultado dramáticamente modificado. ${ }^{4}$ Pues bien, el CT de 1931 guardó silencio respecto del instituto de la interrupción civil de la prescripción. ${ }^{5}$ Lo propio ocurrió originalmente con el DL 2.200 de $1978 .^{6}$ El CT de 1987 rezaba en su artículo 453 inciso final: "Los

${ }^{4}$ Para un panorama sobre la intensa evolución legislativa en materia laboral chilena, vid. Humeres Magnan, H.; Humeres Noguer, H., Derecho del trabajo y de la seguridad social, Editorial Jurídica de Chile, decimocuarta edición, Santiago, 1994, pp. 63-78; Thayer, W., "Legislación laboral y su impacto en la productividad y calidad de vida”, en Revista Chilena de Derecho, Pontificia Universidad Católica de Chile, vol. XXI, núm. I, enero-abril de 1994, pp. 13-20.

${ }^{5}$ En su artículo 89 disponía: "Las acciones y derechos provenientes de los títulos anteriores que no tengan un plazo especial de prescripción, se extinguirán en el término de sesenta días, a contar desde la fecha en que se ponga término a los servicios".

${ }^{6}$ Código del Trabajo de 1978. Su artículo 163 ordenaba: "Las acciones provenientes de los actos y contratos a que se refiere esta ley y de los derechos que en ella se establecen, prescribirán en seis meses contados desde la terminación de los servicios, salvo prescripción especial.

El derecho a reclamar el pago de horas extraordinarias prescribirá en seis meses contados desde la fecha en que debieron ser pagadas.

No podrán reclamarse los derechos derivados de servicios prestados con anterioridad a los dos años que precedan a la fecha de presentación de la demanda, háyase o no puesto término a la prestación de servicios". 
plazos de prescripción establecidos en este Código no se suspenderán, y se interrumpirán en conformidad a las normas de los artículos 2523 y 2524 del Código Civil”. ${ }^{7}$ Tal tenor fue repetido íntegramente en el artículo 480 inciso final del CT de 1994 en su redacción original, que luego pasó a ser inciso cuarto del mismo artículo ${ }^{8}$ y, en el año 1999, inciso quinto. ${ }^{9}$ Por fin, nuevamente fue plasmado el mismo texto en el actual artículo 510 del CT, de acuerdo al cambio de numeración del artículo 480 ordenado por la Ley $\mathrm{N}^{\circ} 20.087 .{ }^{10}$

De esta forma, el inciso quinto del artículo 510 del CT, que a simple vista parece ser de sentido claro, deja de serlo del momento que el artículo $2523 \mathrm{~N}^{\circ} 2$ del CC, que regula la interrupción civil de las llamadas prescripciones de corto tiempo, históricamente ha sido interpretado de diversa forma, tanto en doctrina como en jurisprudencia. Su revisión, aunque reconozco su clasicismo, la considero oportuna para refrescar la memoria.

Dispone dicha norma: "Las prescripciones mencionadas en los dos artículos precedentes corren contra toda clase de personas y no admiten suspensión alguna.

Interrúmpense: (...);

$2^{\circ}$. Desde que interviene requerimiento.

En ambos casos sucede a la prescripción de corto tiempo la del artículo 2515”.

Acerca de qué se ha entendido por la voz requerimiento, se han asentado dos tesis doctrinales y jurisprudenciales contrapuestas, recapituladas sintéticamente de la siguiente forma:

a). Según la primera, para interrumpir civilmente el lapso de tiempo transcurrido y dejarlo íntegramente sin efecto -de manera de considerar que el acreedor ha salido de su inactividad- es necesario un requerimiento judicial, sea cual fuere su especie mientras su género sea judicial. Así, interrumpe la prescripción de corto tiempo la solicitud de otorgamiento de un privilegio de pobreza, la interposición de solicitud de una medida prejudicial precautoria que se lleve a efecto desde luego, o incluso la interposición de

${ }^{7}$ De acuerdo al establecimiento de la historia fidedigna de este tenor, se debe puntualizar que el DL 2.200 de 1978 fue modificado por la Ley $\mathrm{N}^{\circ} 18.018$ de 14 de agosto de 1981, que en su artículo $1 \mathrm{~N}^{\circ} 70$ dispuso: "Sustitúyese el artículo 163 por el siguiente:

Los derechos regidos por la presente ley prescribirán en el plazo de dos años contados desde la fecha en que se hicieron exigibles.

En todo caso, las acciones provenientes de los actos y contratos a que se refiere esta ley prescribirán en seis meses, contados desde la fecha de terminación de los servicios.

El derecho al cobro de sobresueldo por horas extraordinarias prescribirá en seis meses contados desde la fecha en que debieron ser pagadas.

Los plazos de prescripción establecidos en este artículo no se suspenderán y sólo se interrumpirán por demanda judicial”.

Por su parte, la Ley $\mathrm{N}^{\circ} 18.372$ de 17 de diciembre de 1984 consagró en el artículo 1 No 36: "Reemplázase el inciso final del artículo 163 por el siguiente:

Los plazos de prescripción establecidos en este artículo no se suspenderán, y se interrumpirán en conformidad a las normas de los artículos 2523 y 2524 del Código Civil”.

${ }^{8}$ Debido la incorporación de un nuevo inciso final luego de la modificación introducida por la Ley $\mathrm{N}^{\circ} 19.447$, de 8 de febrero de 1996.

9 Tras nuevo inciso segundo intercalado por modificación introducida por la Ley $\mathrm{N}^{\circ} 19.631$, de 28 de septiembre de 1999.

${ }^{10}$ Diario Oficial de 3 de enero de 2006. 
una demanda ante un tribunal incompetente. Como argumento, se señala de que así resulta de entender al requerimiento según su sentido natural y obvio ${ }^{11}$ y de la propia naturaleza de las cosas, atendido a que se trata de una noción que en la jerga procesal constituye un acto de comunicación para comenzar con el orden consecutivo legal. Lo que se hace, en definitiva, es una construcción a pari ratione con la interrupción civil de la prescripción adquisitiva regulada en el artículo 2503 del CC y la interrupción civil en la prescripción extintiva de largo tiempo del artículo 2518 del mismo Código, todos casos en que según tenor literal se requiere demanda judicial. ${ }^{12}$

b). La segunda opinión ${ }^{13}$ estima que se cumple con el requisito legal aún con un requerimiento que no sea de tipo judicial. Lo considera así, en primer lugar, porque el fundamento de las prescripciones de corto tiempo radica en una presunción de pago por parte del deudor y la carencia de prueba escrita justifica que se otorguen al acreedor facilidades para destruir dicha presunción. Por ende, se excepciona la regla general, bastando el mero requerimiento extrajudicial para hacer cesar el tiempo de prescripción transcurrido. En segundo lugar, se menciona que tratándose de la interrupción civil de este tipo de prescripciones, no cabe el fenómeno de la interversión. ${ }^{14}$ En tercer lugar, por una razón histórica que demuestra un cambio de ánimo en el legislador, puesto que en el proyecto inédito de CC se consagró un artículo 2705 de exacto tenor al actual 2523, norma que luego exigió en el proyecto de 1853 demanda judicial para interrumpir la prescripción de corto tiempo, pero que finalmente don Andrés Bello dejó igual al proyecto inédito, esto es, tal como actualmente conocemos, exigiendo sólo requerimiento. ${ }^{15}$ En cuarto lugar, por cuanto el sentido natural y obvio de la expresión también involucra una gestión extrajudicial. ${ }^{16}$ Por último, la Corte Suprema así lo ha resuelto expresamente. ${ }^{17}$

${ }^{11}$ La Real Academia Española define requerimiento como "acto judicial mediante el cual se intima a alguien para que haga o deje de hacer una cosa”. Diccionario de la Lengua Española, Tomo IX, Editorial Espasa, vigésima segunda edición, Madrid, 2001, p. 1325.

12 Para toda esta primera corriente, cfr.: Vásquez, G., La prescripción, Editorial Jurídica La Ley, Santiago, 1995, pp. 183-184; Camiruaga, J.R., De las notificaciones, Editorial Jurídica de Chile, tercera edición, Santiago, 1991, pp. 24-26; Alessandri, A., Teoría de las obligaciones, Editorial Ediar-ConoSur Ltda., Santiago, 1988, p. 487.

13 Adscrita por importante doctrina nacional. Cfr.: Alessandri, A.; Somarriva, M.; Vodanovic, A., Tratado de las obligaciones, vol. III, Editorial Jurídica de Chile, segunda edición, Santiago, 2004, pp. 225-227; Abeliuk, R., Las obligaciones, Tomo II, Editorial Jurídica de Chile, Santiago, 1993, pp. 1029-1030.

${ }^{14}$ Luces sobre este concepto se dan en la parte final de este trabajo. Vid. nota núm. 67.

${ }^{15}$ Relativo a la prescripción, el proyecto inédito del CC y el proyecto de 1853 se encuentran disponibles en Vásquez, G., La prescripción, op. cit., pp. 228-260.

${ }^{16} \mathrm{La}$ RAE también concibe a la expresión requerimiento como "el acto por el cual se reclama a alguien para que entregue, haga o deje de hacer alguna cosa”. En el mismo sentido, De Santo, haciendo referencia a un Diccionario de Derecho Procesal, consagra que "requerimiento también es el aviso, manifestación o pregunta que se hace, por lo general bajo fe notarial, a alguna persona, exigiendo o solicitando de ella que exprese y declare su actitud o respuesta”. De Santo, V., citado por Alessandri; Somarriva; Vodanovic, en Tratado de las obligaciones, op. cit., p. 225. Otro tanto ocurre con la definición de De La Plaza, para quien requerimiento es "un acto formal de intimación que se dirige a una persona, sea o no litigante, para que haga o deje de hacer una cosa”. De La Plaza, M., citado por Camiruaga, J.R., en De las notificaciones, op. cit., p. 25.

${ }^{17}$ RDJ., T. LXIV, Sec. $1^{\text {a }}$, p. 236 , cons. $3^{\circ}$; RDJ., T. I, Segunda parte, p. 284 , cons. $2^{\circ}$. 
En relación al rol de la notificación, sea del recurso judicial o del requerimiento extrajudicial -según la posición que se adopte- también ha existido doctrina y jurisprudencia dispar. $^{18}$

En consecuencia, esta discusión civil ha repercutido en el Derecho Laboral y la interrogante que surge inmediatamente es: ¿Qué criterio ha prevalecido? La cuestión de determinar el momento interruptivo civil de la prescripción laboral ha pasado por decidir si darle preeminencia al valor de la seguridad jurídica o a alguna aplicación concreta del principio de la protección. La respuesta viene dada en la exposición de dos posturas jurisprudenciales anisómeras emanadas de los tribunales superiores de justicia del país, repetidas en sus dos sentidos sin mayor interés por la doctrina laboral nacional.

\section{Primera postura. La Corte Suprema y el argumento de la protección-abuso}

La jurisprudencia del Alto Tribunal, conociendo por la vía de recursos de casación en el fondo, se ha uniformado en adoptar la tesis de quienes piensan que la voz requerimiento del artículo 2523 del CC se refiere a una demanda judicial legalmente notificada, ${ }^{19}$ de forma tal que antes de tal supuesto adjetivo, el lapso de tiempo fluye sin que evento alguno lo haya alterado. Abiertamente, resolvió en causa rol 5503-03; (4) "Que, por otro lado, en lo atinente a la interrupción de la prescripción, este Tribunal ya ha decidido, reiteradamente, que para que opere tal institución resulta necesaria la notificación de la demanda respectiva. Ello porque el legislador laboral se ha remitido expresamente y sólo para los efectos de la interrupción, a los artículos 2523 y 2524 del Código Civil. La primera de esas disposiciones establece que las prescripciones se interrumpen 'desde que interviene requerimiento’ y la norma contenida en el artículo 2503 prescribe que sólo quien ha intentado todo recurso judicial puede alegar la interrupción y ni aún él si la notificación de la demanda no ha sido hecha en forma legal"; (5 ) "Que, bajo el pretexto del carácter tuitivo del derecho laboral y de sus especiales características, no es dable colocar a las partes litigantes en desigualdad procesal y eximir.

\section{Segunda Postura. Cortes de Apelaciones}

Mutatis mutandi, diversos fallos de distintas Cortes de Apelaciones -reconociendo la necesidad de un requerimiento de tipo judicial (demanda judicial) - mantienen que es bastante para interrumpir la prescripción su presentación ante el juzgado de turno o

18 Vid. Domínguez, R., La prescripción extintiva. Doctrina y jurisprudencia, Editorial Jurídica de Chile, primera edición, Santiago, 2004, pp. 355-356. Este autor cita jurisprudencia discrepante, pero en cuanto al requerimiento extrajudicial, textualmente, considera que "si el requerimiento fuese extrajudicial, entendemos que debe llegar al conocimiento del deudor, porque no se entendería que produjese efecto una exigencia de pago que permaneciese en la esfera del acreedor, sin que el deudor la conozca. Por su naturaleza, ese requerimiento se hace cuando se dirige al deudor, a menos que, siendo escrito, pudiera probarse que se envió en tiempo aunque se recepcionó más tarde. Entendemos que aquí el requerimiento por su naturaleza es claramente recepticio. Todo radica entonces en un problema de prueba”. Domínguez, R., loc. cit., p. 356.

${ }^{19}$ Alguna doctrina ha demostrado que existe jurisprudencia de la Corte Suprema donde se acepta el efecto interruptivo con la sola presentación de la demanda. Vid. Rodríguez, A., Legislación del trabajo y de la seguridad social, Tomo I, Ediar-ConoSur Ltda., edición sin fecha impresa, Santiago, p. 302. 
su ingreso a distribución en la Corte respectiva, según el caso. Este parecer dibuja entre líneas un fundamento tutelar. Por ejemplo, la Corte de Santiago en sentencia de 8 de enero de $2008,{ }^{20}$ causa rol 2327-07, declara que: $\left(5^{\circ}\right)$ "No es irrelevante enfatizar que se está en presencia de un derecho especial, singularizado por su carácter protectivo a los intereses de la parte de los trabajadores; (...) debe también ponerse de relieve que se trata de un plazo particularmente breve, de los más exiguos en nuestra legislación, que determina la extinción definitiva de un derecho y, en fin, que el fundamento último de las prescripciones de corto tiempo es la presunción de pago que favorece al deudor, en el sentido de que la inactividad del acreedor hace presumir la extinción de la deuda"; $\left(6^{\circ}\right)$ "Que, a propósito del numeral $2^{\circ}$ del artículo 2523 del Código Civil, se ha dicho que la voz requerimiento - diferente del término demanda y recurso judicial que emplean sus artículos 2518 y 2503- ha de asumirse como alusiva a cualquier acto, judicial o extrajudicial, dirigido a obtener el cumplimiento de una obligación, en el sentido de que la brevedad del plazo de prescripción hace necesario otorgar al acreedor las facilidades necesarias para disipar o destruir aquella presunción de pago"; $\left(7^{\circ}\right)$ "Que, de esta manera, no puede sino concluirse que, para los fines del inciso cuarto del artículo 480 del Código del Trabajo, esto es, para interrumpir el curso del plazo de esta prescripción de corto tiempo, basta con la interposición o presentación de la demanda, desde que tal actuación es suficiente para evidenciar el cese en la inactividad del acreedor sin que sea obstáculo para ello la función estabilizadora, inmanente a la prescripción, desde que la misma no puede dar pie para que se favorezca el incumplimiento de las obligaciones”. ${ }^{21,22,23}$

${ }^{20}$ L\&S, N ${ }^{\circ}$ 56, enero de 2008, pp. 53-54.

${ }^{21}$ La misma Corte, en sentencia de 10 de noviembre de 2005, causa rol 973-2005, manifiesta que: ( $7^{\circ}$ letra b) "Tal distinción (del requerimiento exigido en el artículo 2503 en relación al $2523 \mathrm{~N}^{\circ} 2 \mathrm{CC}$ ) para que sea útil en el ámbito laboral y justifique la referencia que hace el artículo 480 del Código del Trabajo al artículo 2523 del Código Civil, parece indicar claramente que el legislador pretendió, efectivamente, darle a la interrupción de la prescripción en este ámbito, un tratamiento especial, similar o análogo al que tiene la interrupción en las prescripciones de corto tiempo, donde la exigencia de requerimiento, a secas, ha sido interpretado en términos menos estrictos que la demanda judicial a la que se refiere el artículo 2518 del Código Civil para las prescripciones de largo tiempo, o el recurso judicial exigido para la adquisitiva en el 2503 de ese cuerpo legal"; ( $7^{\circ}$ letra d) "En el mismo sentido orientan los principios pro operario e indubio pro operario, de clara y reconocida vigencia y aplicación en el Derecho Laboral”. Continúa este fallo argumentando sobre principios: ( $7^{\circ}$ letra e) "Que, igualmente sucede con la idea o principio de la primacía de la realidad, también de innegable aplicación en lo laboral. En efecto, sabido es que el trabajador, frente a una cesación involuntaria de los servicios, consume el tiempo inmediato a ese hecho entre el impacto propio del mismo, los trámites ante la Inspección del Trabajo, los propios de la búsqueda de un nuevo trabajo y la contratación de servicios letrados para el juicio; todo lo cual puede precipitarlo rápidamente al término de seis meses de la prescripción, sin que logre en ese período tan breve notificar la demanda; situación que es aún más grave si su defensa es gratuita - por su estado de pobreza- pues la inactividad pertinente a la notificación puede verse severamente retardada, como lo refieren en estado los postulantes que hacen su práctica en las respectivas instituciones públicas o privadas". L\&S, N ${ }^{\circ} 5,28$ de noviembre a 11 de diciembre de 2005, pp. 85-86.

${ }^{22}$ Ejemplos en el mismo sentido anterior: RDJ., T. LXXXIX, Sec. $3^{\mathrm{a}}$, p. 133 , cons. $1^{\circ}$ y $2^{\circ}$; Corte de San Miguel, sentencia de causa rol 340-2006 de 9 de agosto de 2006, cons. $1^{\circ}$ y $2^{\circ}$.

${ }^{23}$ Para sentencias en contra de la Corte de Santiago, vid. Rioseco Enríquez, E., La prescripción extintiva ante la jurisprudencia, Editorial Jurídica de Chile, primera edición, Santiago, 1994, pp. 72-73; Corte de 


\section{II. ¿RESULTA SER EN LA ACTUALIDAD SUFICIENTEMENTE JUSTIFICABLE LA APLICACIÓN DEL CÓdIGO CIVIL EN LA MATERIA COMENTADA?}

Para fundar la negativa, que creo desde luego procedente, iniciaré la argumentación complementando algunas ideas que mencioné acerca de la dicotomía teleológica existente entre el Derecho Civil y Laboral, más las distinciones que luego de ella formulo.

La conceptualización conocida del Derecho Civil como el derecho privado común y general, autoriza y legitima, en primer término, el reenvío hecho por el CT a la norma civil. También, de conocida laya es la dualidad de fundamento que concierne a la institución de la prescripción: desde un punto de vista subjetivo, como sanción a la inactividad del acreedor; desde un punto de vista objetivo, como una tutela al orden público mediante la consolidación de situaciones jurídicas y ulterior concreción del valor de la seguridad jurídica. ${ }^{24} \mathrm{Y}$ más allá de estos lineamientos básicos que conectados con cualquier área del derecho resultan transversales, el Derecho Laboral, por una cuestión de naturaleza y principios, debe considerarse separado del Derecho Civil.

Considérese que la boga que tuvo el estudio del Derecho Obrero en el siglo pasado se explicó por la incapacidad del Derecho Civil de dar una respuesta adecuada a la cuestión social derivada del trabajo. Basado en gran parte en el laissez faire del negocio jurídico como vehículo de autonomía privada y reconociendo la igualdad de posiciones de los particulares, el Derecho Común se limita a establecer un piso mínimo de protección de los actores a partir de la consagración de condiciones legales de existencia y vigor -requisitospara que el mecanismo del negocio jurídico produzca (y sanos) los fines particularmente deseados. En caso de inobservancia de dichas exigencias legales, actúan las normas que establecen consecuencias o sanciones. En definitiva, el Derecho Civil, acaso teniendo como piedra angular la noción de autonomía de la voluntad y el dominio, no coincide con el fundamento de la norma laboral. Ésta se basa en la desigualdad que importa el sometimiento del trabajador - por necesidad inevitable como medio de subsistencia- a una relación de dependencia y subordinación a favor de un empleador a quien entrega su fuerza de trabajo a cambio de una remuneración estipulada. Como señala Gamonal: "Dejar al trabajador sujeto a la autonomía privada y al mercado importa cosificarlo y convertirlo en un verdadero objeto de derecho, disponible al mejor postor". ${ }^{25}$

Concepción, en L\&S, N 45, agosto de 2007, pp. 78-80; Corte de Valdivia, en sentencia de 24 de julio de 2009, causa rol 58-2009, donde se limita a remitirse a la doctrina de la Corte Suprema expuesta.

${ }^{24}$ En este segundo sentido, Josserand escribe: "La prescripción tiene un carácter de orden público, no sólo porque constituye un medio de prueba socialmente necesario, sino también porque presenta la ventaja de evitar averiguaciones difíciles, de conjurar contiendas tardías, de poner término a reclamaciones póstumas y a la chicana; un proceso motivado por un crédito de un siglo o más suscitaría cuestiones de hecho y derecho cuya solución sería difícil: la seguridad jurídica exige que se ponga un término a las reivindicaciones y en sus comienzos". Josserand, L., Teoría general de las obligaciones, Editorial Parlamento, Santiago, 2008, p. 584.

${ }^{25}$ Gamonal, S., Fundamentos de derecho laboral, op. cit., p. 104. Por su parte, Castorena observa que "el Derecho Obrero ve derogaciones a los principios del Derecho Común; se trata a éste como una reliquia histórica: el Derecho Obrero es el derecho nuevo, lozano, de una pujanza insospechada; se afirma que está 
Emergió entonces el Derecho Laboral como una disciplina substantivamente distinta $^{26}$ y que goza de autonomía legislativa, científica y jurisdiccional, ${ }^{27}$ más la independencia originada en el establecimiento indiscutido del principio de la protección y sus ramificaciones, ${ }^{28}$ como fundamento primario de su regulación.

\section{Desde la exégesis: facta non verba}

Si se pretende darle plena consolidación a los fundamentos de la prescripción liberatoria, sus supuestos de aplicación deben estar construidos en un andamiaje legal que tenga un sentido lo más claro posible. De otra forma la seguridad jurídica temblaría abstractamente desde sus inicios; desde antes de llevarla a una aplicación en la especie.

El antecedente inicial del artículo 510 inciso quinto del CT se encuentra en el artículo $1 \mathrm{~N}^{\circ} 70$ de la Ley $\mathrm{N}^{\circ}$ 18.018, que sustituyó el artículo 163 del DL 2.200 de 1978 y exigió en su inciso final demanda judicial para interrumpir la prescripción. Luego, en el año 1984, la Ley N 18.372 (conocida como "ley del rastrillo"), modificó el mismo artículo y consagró el tenor que ha perdurado hasta ahora. ${ }^{29}$ La variación de criterio legal demuestra entonces que existe un problema que trató de ser resuelto en forma legislativa, que por cierto no lo fue suficientemente, si se considera que el criterio anterior sigue siendo actualmente el aplicable por parte de la jurisprudencia.

En todo caso, desde una perspectiva legalista estricta y asumiendo inevitablemente los riesgos de mover discusiones civiles a sede laboral, ${ }^{30}$ sostengo que la remisión

llano a transformarlo todo, a inyectar vida al Derecho Privado". Castorena, citado por Cabanellas, G., en Tratado de derecho laboral, Tomo I, vol. I, Editorial Claridad S.A., Buenos Aires, 1988, p. 434.

${ }^{26}$ Cuestión reflejada en el artículo 5 del CT al menos en dos aspectos. Por un lado, la proscripción de la renuncia anticipada de los derechos laborales no coincide con la ratio legis del artículo 12 del CC; por otro, en el marco del concepto de ciudadanía al interior de la empresa y los llamados derechos fundamentales laborales inespecíficos, se ha entendido que la norma establece la eficacia horizontal (interpartes) de dichos derechos al interior de la empresa, porque son exigibles por el trabajador directamente al empleador, estando adjetivamente protegidos por el procedimiento de tutela introducido por la Ley 20.087. Cfr. Ugarte, J.L., "La tutela de derechos fundamentales y el derecho del trabajo: de erizo a zorro", en Revista de Derecho, Universidad Austral de Chile, vol. XX, núm. 2, diciembre de 2007, pp. 51-59; Caamaño, E., "La tutela jurisdiccional de la libertad sindical”, en Revista de Derecho, Universidad Austral de Chile, vol. XIX, núm. 1 , julio 2006, pp. 86-88.

${ }^{27}$ Cfr. Cabanellas, G., Tratado de derecho laboral, op. cit., pp. 433-442.

${ }^{28}$ Seguimos la sistematización de Gamonal, para quien el principio de la protección tiene manifestaciones concretas, a saber, la regla in dubio pro operario; la regla de la norma más favorable; la regla de la condición más beneficiosa; la irrenunciabilidad de los derechos; la continuidad o estabilidad laboral, y la primacía de la realidad. Gamonal, S., Fundamentos de derecho laboral, op. cit., p. 105.

${ }^{29}$ Vid. nota núm. 6.

${ }^{30}$ Piénsese, por ejemplo, que tan clásica como el alcance de la voz requerimiento del artículo 2523 del CC, es la licitud y procedencia de los pactos privados que adelantan o retrasan los términos de prescripción. Partiendo de la seguridad jurídica, no se aceptan aquellos que los retrasan, justamente por atentar contra dicho valor. Respecto de los pactos que adelantan la prescripción, cuando se han aceptado, se ha dicho que juegan de manera precisa a favor de dicho principio y que el CC los ha aceptado en forma expresa en el caso del artículo 1866 (acción redhibitoria). Considerando que en la interrupción civil las normas de la prescripción 
ordenada por el CT permite afirmar de manera razonable que basta la presentación de la demanda, sea ante el juzgado de turno o a distribución en la Corte respectiva, para interrumpir la prescripción en materia laboral, como interpretación más favorable al trabajador en el caso sub lite.

Primeramente, el requerimiento establecido en el artículo 2523 del CC debe entenderse en materia laboral como interposición de demanda judicial ${ }^{31}$ o su ingreso a distribución. Partiendo de este postulado inicial y considerando que los términos de prescripción establecidos en el CT son unos de los más breves que considera el ordenamiento jurídico en general, ${ }^{32}$ no resulta justo exigir además la notificación legal de la demanda dentro de plazo para producir el efecto interruptivo. Ello por una razón lógica que atenta contra el espíritu de la ley: es perfectamente aplicable aquí la postura de Peñailillo, para quien "si se exige que también la notificación se practique dentro del plazo, en la realidad al que quiere interrumpir (dueño o acreedor, según el caso) se le estaría restando plazo; más aún, a algunos se les estaría confiriendo menos plazo que a otros; es así porque, como tiene que preocuparse de notificar, tendría que salir de su inactividad un tiempo antes de vencerse el plazo, y si el demandado es de difícil ubicación, el respectivo actor tendría menos plazo que otro cuyo demandado es de muy fácil notificación (a lo que puede agregarse la posibilidad de que el demandado despliegue maniobras para evadir o postergar la notificación); esa desigualdad no es aceptable y se evita con esta alternativa". 33

Podría afirmarse que la alternativa anterior pugna con los efectos básicos del emplazamiento procesal y que las resoluciones judiciales sólo producen efecto a partir de su notificación válida. Pero como continuara escribiendo Peñailillo: “(...) es útil tener presente una distinción entre los efectos substantivos y procesales de la demanda. Substantivamente, constituye la protesta ante el tribunal por custodiar el derecho;

adquisitiva y extintiva de largo tiempo se han aplicado por analogía a las de corto tiempo y esta solución ha sido aplicada al CT, podría pensarse que es válido el pacto en que el empleador acuerda con el trabajador que una vez terminado el contrato se reducirá el plazo de seis meses que tiene para ejercitar las acciones que emanen del contrato de trabajo, o de nulidad del despido, a tres, lo que haría en la práctica inviable en su totalidad la interposición oportuna de la acción. Empero, esta solución choca absolutamente con el carácter de orden público de la norma laboral y la irrenunciabilidad anticipada de los derechos laborales.

${ }^{31} \mathrm{La}$ argumentación que mantengo es perfectamente aplicable a la interposición de una demanda ante tribunal incompetente o con otro tipo de recursos judiciales, tales como la tramitación previa de un privilegio de pobreza o la interposición de una medida prejudicial.

${ }^{32} \mathrm{~V}$. gr., seis meses contados desde la terminación de los servicios para ejercer las acciones provenientes de actos y contratos a que se refiere el CT, para reclamar de la nulidad del despido y para el cobro de horas extraordinarias; en este último caso, contados desde que debieron ser pagadas. Ni siquiera títulos de crédito como el cheque, cuya regulación descansa en el poderoso axioma de ser actos jurídicos abstractos y donde la irrelevancia de causa juega precisamente como mecanismo de protección del tráfico jurídico, cuestión también vinculada a la fe pública, tienen un plazo de prescripción tan corto, donde, como se recuerda, de acuerdo a la ley sobre cuentas corrientes bancarias y cheques, tanto la acción ejecutiva para el cobro del cheque protestado como la penal, prescriben en un año contado desde la fecha del protesto.

33 Peñailillo, D., Los bienes, la propiedad y otros derechos reales, Editorial Jurídica de Chile, primera edición, Santiago, 2006, pp. 415-416. 
procesalmente, inicia el juicio respectivo; con la notificación queda trabado el juicio y cobra eficacia el acto interruptivo, pero que ya quedó configurado al presentarse la demanda. Esta distinción fortalece la conclusión de que basta que la demanda sea presentada dentro del plazo, aunque la notificación se practique después”. ${ }^{34}$ En otras palabras, puede decirse que el ingreso de la demanda o su presentación dentro de plazo prepara el efecto interruptivo, pero mientras la notificación de la misma no se produzca, tal efecto queda en suspenso, de forma que si ella se practicó ulteriormente conforme a derecho, la interrupción se retrotrae a la fecha de presentación del libelo y entonces, en tal oportunidad, se produce la pérdida de todo el lapso de tiempo transcurrido para extinguir la acción por prescripción. Como puede darse el caso que transcurra bastante tiempo entre la presentación y la notificación, es necesario morigerar esta doctrina con el establecimiento de una cláusula de dureza en cuanto a considerar un tiempo máximo prudencial entre la separación del dependiente o el término de los servicios ${ }^{35}$ y la notificación de la demanda.

La interpretación expuesta está intentada tomando en cuenta que la génesis del efecto interruptivo radica en las maniobras que ejecuta el trabajador, acreedor de esta relación desigual, para salir de su inactividad y reclamar su derecho. Generalmente, un trabajador medio, ante un despido que considera injustificado y las consecuencias más o menos traumáticas que en él produce, concurre tan presto como es posible a la Inspección del Trabajo a dejar noticia y constancia de tal evento. A partir de aquello, prepara, con los documentos que tiene a su disposición (en su caso el anexo de reclamo y copia del acta de comparendo ante la Inspección del Trabajo), su entrada en juicio. Para ello, tras optar forzadamente en muchos casos por la asesoría de la Corporación de Asistencia Judicial de su domicilio, le pide a algún colega en funciones el gran favor de atestiguar en juicio a su favor y que le consiga algún documento probatorio, v. gr., copia de un libro de asistencia. Paralelamente, intenta subsistir él y su familia buscando otra fuente de empleo.

Por otro lado, tanto en los hechos como en el derecho, la interrupción no depende sólo de la voluntad del trabajador encaminada a salir de la inactividad, como suficientemente se demuestra con la presentación de su demanda, sino que también de la práctica de actos procesales de los cuales no tiene el manejo, como ser el traslado proveído luego de la presentación (en el procedimiento de aplicación general antes de reformado) y la diligencia que tenga el auxiliar de la administración de justicia conocido como receptor judicial o actualmente algún funcionario notificador. ${ }^{36}$ Ello ha redundado en una

${ }^{34}$ Loc. cit., p. 415. Vid., además, Barrera, J., El procedimiento laboral en el nuevo Código del Trabajo, Ediciones Jurídicas La Ley, tercera edición actualizada, Santiago, 1993, pp. 79-83.

35 En Derecho Laboral, este es el único criterio admisible a partir del cual contar el lapso de prescripción, según se explicará.

36 Reconociendo esta realidad, la Corte de Antofagasta en sentencia rol 95-07 de 29 de junio de 2007, en su considerando cuarto consagra: "Que no obstante lo razonado, surge la necesidad de destacar que tratándose de procesos, cuyos procedimientos están regulados por el Código del Trabajo, la protección del trabajador constituye uno de los fines específicos y, por ello, se explica que algunos Juzgados del Trabajo 
gran cantidad de casos en una demora importante entre la presentación del libelo y su notificación, importando un gravamen procesal ${ }^{37}$ para el trabajador, quien tramitará un procedimiento que resultará en la extinción de su acción por haberse acogido una excepción de prescripción ${ }^{38}$ por dilación en la práctica de actos que no le empecen, restándole ocurrir a los buenos oficios del ex empleador para que cumpla con su obligación, ahora transformada en natural. A mayor abundamiento, actualmente de acuerdo a las normas que regulan ciertos principios formativos del procedimiento y notificación de la demanda (artículos 425, 429 y 436 del CT), rige plenamente el impulso procesal de oficio, lo que reafirma que el manejo de la prosecución del procedimiento no depende completamente del dependiente.

El razonamiento que ha tenido la jurisprudencia de los tribunales superiores de justicia chilenos en esta materia - tal como fuera ilustrado con anterioridad- ha sido

tienen en su planta de personal un receptor laboral, con el objeto de agilizar las notificaciones e impedir que los trabajadores demandantes incurran en gastos previos a la gestión; para este mismo fin, la Corporación de Asistencia Judicial tiene asignado un Receptor, por lo que las notificaciones de las demandas y demás resoluciones, no dependen de las partes, sino de la actuación de este auxiliar de la Administración de Justicia”. L\&S, No 43, julio de 2007, p. 98.

37 Doblemente perjudicial si se considera el efecto práctico que la citación al comparendo ante la Inspección del Trabajo produce para el empleador. En general se celebra en su rebeldía, y si con su presencia, en muy pocas oportunidades se logra algún acuerdo, de manera que el mismo mediador le repite al trabajador que tiene el derecho de recurrir a los tribunales de justicia asesorado por medio de abogado particular o por la Corporación de Asistencia Judicial. En la actualidad existe la Defensoría Laboral. Quienquiera que sea, como el empleador sabe que probablemente el trabajador inicie un juicio laboral en su contra, es muy frecuente que despliegue maniobras fraudulentas para burlar su paradero. Si pensamos en la tramitación que supone la notificación personal subsidiaria del artículo 437 CT (anterior 431) -de resultar fallida la notificación personal de la demanda- y la práctica efectiva de la diligencia, entonces lo que ocurre es que en realidad el trabajador tiene que salir de su inactividad mucho tiempo antes de que transcurra el lapso de prescripción, llevando al extremo la situación si por la fuerza de los hechos es necesario iniciar una tramitación vía exhorto. Lo mismo sucede con el demandado que vive en una localidad alejada, caso en el cual el juez -no existiendo receptor particular- puede ordenar la práctica de la diligencia a Carabineros de Chile, mecanismo que se inicia con la remisión de un oficio a la comisaría en que se encarga la solicitud, la realización de la misma y el envío al tribunal de su resultado positivo o negativo. Por otro lado, y en una gran cantidad de veces, el trabajador debe optar por la representación de la Corporación de Asistencia Judicial. Dicho mecanismo de defensa, si bien pretende hacer efectivo el mandato del artículo $19 \mathrm{~N}^{\circ} 3$ incisos uno, dos y sobre todo tres de la CPR, en la práctica adolece de una serie de trabas administrativas para que una persona obtenga la calificación de "consultante" y por fin iniciar la representación ante tribunales. A ello debe agregarse que en algunos consultorios la escasa dotación de plantel profesional y la gran cantidad de causas asignadas a cada postulante (al título de abogado), junto con el trabajo del único receptor, impide por esta sola circunstancia una tramitación oportuna. Vid. críticas a este sistema de defensa en Balmaceda, N., "Corporaciones de asistencia judicial y abogados de turno: ¿Incumplimiento de una garantía constitucional?”, en Revista Chilena de Derecho, vol. 27, núm. 4, octubre-diciembre de 2000, pp. 721-731, passim.

${ }^{38}$ Luego de la reforma al procedimiento de aplicación general, esta excepción se debe oponer por escrito en la contestación de la demanda cinco días antes de la audiencia preparatoria y el juez la falla en dicha oportunidad luego de conferir traslado y contestado éste por la parte demandante. Contra la resolución que se pronuncia sobre ella procede solamente el recurso de apelación fundado, el que se concede en ambos efectos y se ve en cuenta en la Corte. Antes de la dictación de la Ley N $\mathrm{N}^{\mathrm{2}} 20.087$, la excepción se oponía también en el escrito de contestación, pero se confería traslado y se dejaba su resolución para definitiva. 
de un marcado carácter legalista; romántico podríamos decir o una invitación a volver al razonamiento del liberalismo decimonónico, al juez silogista descrito por Montesquieu como boca que pronuncia palabras de la ley. ${ }^{39}$ Las sentencias donde se falla una excepción de prescripción laboral constan de verdaderos considerandos resolutivos donde se analizan sólo los tres momentos que sugieren la solución: fecha de despido, interposición de demanda, notificación de demanda. El argumento primario para acoger la excepción de prescripción ha radicado en endurecer el criterio establecido en la norma del artículo 2523 del CC. No pareciera razonable que, por un lado, en materia civil se ha aceptado con las mismas normas legales que basta el requerimiento extrajudicial para interrumpir la prescripción de corto tiempo y, por otro, en materia laboral manifestar que el requerimiento se refiere a una demanda judicial legalmente notificada, como lo dice la CS.

Tampoco ayuda mucho el denominado fundamento de las prescripciones de corto tiempo. Su aplicación a una cuestión laboral conllevaría a la siguiente paradoja: considerar que el plazo de seis meses que tiene el trabajador para iniciar una acción de despido injustificado más cobro de prestaciones, o de nulidad del despido, radica en una presunción de pago por parte del deudor (empleador) y que ante la carencia de medio escrito por parte de éste resulta justificado establecer aquel lapso de tiempo tan corto para que así se consolide una situación jurídica que para él pende de una prueba dura, no se condice en lo absoluto con la fuerza que despliega la subordinación y dependencia, si en los hechos el que carece de medio escrito suele ser precisamente el acreedor (trabajador): o porque ante su petición -siendo consensual el contrato de trabajo, como se sabe- nunca se le otorgó éste por escrito, o porque todo tipo de registro permanece en manos del empleador. En los dos casos descritos la dependencia y subordinación explica que el trabajador ante su incipiente trabajo, confiando en la buena fe de las personas, prefiere trabajar callado y no utilizar ningún medio legal para apremiar al empleador, so pena de quedar cesante; pero si esto último ocurre y entra en juicio, su desafío muchas veces será aún mayor: probar la relación laboral. ${ }^{40,41}$

${ }^{39} \mathrm{Al}$ respecto, vid. ácidas críticas al razonamiento de la CS sobre el principio dispositivo y el orden consecutivo en Hunter, I., “ ¿Tiene el tribunal algún deber en orden al impulso procesal en el actual proceso civil chileno?", en Revista de Derecho (Jurisprudencia Comentada), Universidad Austral de Chile, vol. XXII, núm. 1, julio de 2009, pp. 269-274.

${ }^{40}$ Para Domínguez, "el sistema especial que contiene el Código para las prescripciones de corto tiempo y referido en los artículos 2521 y 2522, de acuerdo a la letra del art. 2523, es propio sólo a ellas y no extensible a otras prescripciones de corto tiempo que no tienen los mismos fundamentos que justifican ese régimen propio”. Domínguez, R., La prescripción extintiva. Doctrina y jurisprudencia, op. cit., p. 351.

${ }^{41}$ En este sentido, se aplaude la modificación de los requisitos de la demanda y de la contestación introducidos por la Ley $\mathrm{N}^{\circ}$ 20.087. Tanto el artículo $446 \mathrm{~N}^{\circ} 4$ del CT como el artículo 452 inciso segundo, exigen la exposición clara y circunstanciada de los hechos de la demanda y de la contestación, respectivamente. De manera adicional, el demandado tiene la carga procesal de pronunciarse sobre los hechos contenidos en la demanda, aceptándolos o negándolos en forma expresa y concreta. Como sanción, de acuerdo al artículo 453 $\mathrm{N}^{\circ} 1$ inciso sexto, si contestando la demanda no negare algunos de los hechos contenidos en ella, deben ser estimados en la sentencia como tácitamente admitidos. Esta norma es muy excepcional, ya que le concede al 
Considerando que todo lo argumentado en este punto puede ser reducido a la trascendencia procesal y práctica de la notificación de la demanda, planteo ahora estas interrogantes: ¿qué pasa si la demanda se interpone y se notifica dentro de plazo, pero posteriormente, conociendo el tribunal de un incidente de nulidad de la notificación, ésta se anula, estando en consecuencia fuera de plazo el actor para practicar la nueva notificación oportunamente? ¿Desde cuándo se considera interrumpida la prescripción? ${ }^{42}$ La respuesta depende de la postura que se adopte. Si se sigue aquella de la CS, debe concluirse que en virtud de la notificación anulada no se interrumpió en lo civil la prescripción laboral, de modo que probablemente cuando ella se efectúe la acción esté prescrita. Y siguiendo la tesis que en este trabajo se adopta, si se anula el acto de comunicación, es irrelevante la práctica de la nueva notificación: el efecto substantivo de la demanda deja indemne el resultado interruptivo.

En definitiva, la teoría de la distinción de los efectos substantivos y adjetivos de la demanda es una alternativa justa en lo laboral, desde un punto de vista político y jurídico. Por una parte, queda custodiado el derecho del trabajador y, por otra, procesalmente el orden consecutivo legal puede desarrollarse con normalidad sin resultar en consecuencias inicuas para el laborante.

\section{A partir de los principios: punto de vista pro operario}

Una fundamentación más acabada de la solución anterior puede ser a partir de este principio. Ello por cuanto, como señala Cabanellas, "el abuso de la interpretación hierática y mecánica de la ley, sacrificando todo el principio general que expresa la misma, sin discriminación alguna, sin armonizar con otros de mayor jerarquía y sin condicionarlo a los preceptos que informan la buena fe y la doctrina del abuso del derecho, conduce, necesariamente, a soluciones no siempre acordes con el sentido de lo humano y de lo justo". ${ }^{43}$ Los argumentos de principios, en palabras de Dworkin, "justifican una decisión política demostrando que tal decisión respeta o asegura algún derecho, individual o del grupo". ${ }^{44} \mathrm{Y}$ eso es lo que precisamente pretende lograr la protección a partir del axioma de la desigualdad. El principio conocido como pro operario es, junto con otros, una derivación de aquel principio matriz, que se concreta en un llamamiento al legislador

juez la facultad de otorgarle valor al silencio. Estas nuevas exigencias pretenden solucionar un problema de onus probandi ocurrido con anterioridad, ya que comúnmente en la contestación el demandado se limitaba a negar la existencia de la relación laboral, desconocía todos los hechos de la demanda y trasladaba toda la carga de aquella difícil prueba al actor. Esta es la verdadera prueba diabólica en materia laboral y este cambio de criterio, tanto respecto de la anterior regulación del procedimiento de aplicación general como en relación a los requisitos de la demanda del artículo 254 del CPC, demuestran una clara adopción del criterio pro operario por parte del legislador.

42 En materia civil el tema ha sido conocido por la CS. Como en la prescripción liberatoria de largo tiempo sí se requiere notificación válida de la demanda para interrumpir la prescripción, la jurisprudencia ha entendido que la notificación anulada no produjo el efecto interruptivo. Vid. RDJ., T. LXXXVII, Sec. $1^{\mathrm{a}}$, p. 21; RDJ., T. LXXXVIII, Sec. 1ª , p. 24; RDJ., T. LXXXIX, Sec. 2a , p. 21.

${ }^{4}$ Cabanellas, G., Tratado de derecho laboral, op. cit., vol. II, p. 36.

${ }^{44}$ Dworkin, R., Los derechos en serio, Editorial Ariel, segunda edición, Barcelona, 1988, p. 148. 
mediante el criterio pro operario al establecer la norma, y al juez al interpretarla, a través de la regla in dubio pro operario. Esta última noción, de acuerdo a doctrina iuslaboralista nacional, consiste "en que frente a diversas maneras de entender una norma ha de preferirse aquella que más favorezca al trabajador. Es decir, se trata de una sola disposición que tiene varios significados distintos". ${ }^{45}$ Su aplicación es al derecho y no a los hechos, como de manera incorrecta se observa a diario en pretensiones argumentadas en base a este principio. No está consagrado formalmente ni en la ley ni en la CPR, a diferencia de lo que ocurre en otros países de la región. ${ }^{46}$ Empero, puede afirmarse que encuentra recepción a partir del denominado principio pro bomine, ${ }^{47}$ consistente en una potente herramienta interpretativa de los derechos humanos a favor de la persona, ${ }^{48}$ que cuenta con consagración positiva en importantes tratados ratificados por Chile y en la actualidad en vigor. ${ }^{49}$ Lo anterior debe necesariamente vincularse con los requisitos que debe contener la sentencia definitiva del procedimiento de aplicación general, consagrados en el artículo 459 del CT, en especial con su numeral quinto, que exige la inclusión de los preceptos constitucionales, legales o los contenidos en tratados internacionales ratificados por Chile y vigentes, las consideraciones jurídicas y los principios de derecho o de equidad en que el fallo se funda. La última conjunción copulativa "y" demuestra que el principio en comento es una herramienta interpretativa efectiva con que el juez debe valorar el derecho aplicable.

\section{Otra consecuencia del análisis: examen de constitucionalidad del artículo 510 del CT}

Los criterios civilistas contenidos en la norma analizada redundan al menos en un germen de inconstitucionalidad. De acuerdo a su inciso primero, los derechos regidos

${ }^{4}$ Sáez, F.; Melis, C., Derecho del trabajo, Tomo I, Editorial ConoSur, Santiago, 2000, p. 33.

46 V. gr., artículo 26 de la Constitución Política de la República del Perú y artículo 48 numeral II de la Constitución Política de Bolivia. El Código Sustantivo del Trabajo de Colombia consagra el principio en sendas disposiciones: artículos 1, 18, 19 y 21.

47 También llamado pro cives o favor libertatis. Vid. Nogueira, H., "Los derechos esenciales o humanos contenidos en los tratados internacionales y su ubicación en el ordenamiento jurídico nacional: Doctrina y jurisprudencia”, en Iux et Praxis, Facultad de Ciencias Jurídicas y Sociales de la Universidad de Talca, vol. 9, núm. 1, 2003, pp. 429-430.

${ }^{48}$ En palabras de Mónica Pinto, "es un criterio hermenéutico que informa todo el derecho de los derechos humanos, en virtud del cual se debe acudir a la norma más amplia, o a la interpretación más extensiva, cuando se trata de reconocer derechos protegidos e, inversamente, a la norma o interpretación más restringida cuando se trata de establecer restricciones permanentes al ejercicio de los derechos o su suspensión extraordinaria. Este principio coincide con el rasgo fundamental del derecho de los derechos humanos, esto es, estar siempre a favor del hombre". Pinto, M., citada por Amaya, A., en "El principio pro homine: Interpretación extensiva vs. el consentimiento del Estado", en International Law: Revista colombiana de Derecho Internacional, Pontificia Universidad Javeriana, Bogotá, núm. 5, junio de 2005, p. 351. Disponible en http://www.javeriana.edu.co/ Facultades/C_Juridicas/pub_rev/int_ediciones.htm [Fecha de revisión: 7 de agosto de 2009].

${ }^{49}$ Vid. artículo 29 de la Convención Americana de Derechos Humanos en relación con el artículo 5.1 del Pacto Internacional de Derechos Civiles y Políticos y 31 de la Convención de Viena sobre el Derecho de los Tratados de 1969. 
por el CT prescribirán en dos años contados desde la fecha en que se hicieron exigibles y, según el inciso cuarto, el derecho al cobro de las horas extraordinarias prescribirá en seis meses contados desde la fecha en que debieron ser pagadas. En otras palabras, el legislador laboral utiliza el criterio del artículo 2514 del CC: se cuenta el tiempo desde que la obligación se haya hecho exigible. Pero como los derechos regidos por el CT y el cobro de horas extraordinarias pueden ser perfectamente exigibles dentro de la relación laboral, el trabajador rara vez - por no decir nunca- va a exigir o demandar su cumplimiento en esa oportunidad, por la sencilla razón de que se somete al riesgo intolerable de ser despedido. Ocurre entonces que, contra su querer interno, permanece en inactividad y termina por prescribir su acción. En otras palabras, se produce una renuncia tácita ahí donde el principio de la irrenunciabilidad anticipada y el orden público laboral la prohíbe expresamente. En estos casos, tampoco está amparado el trabajador con algún mecanismo de suspensión de la prescripción durante la vigencia de la relación laboral, por lo que el único criterio para contabilizar los plazos de prescripción tiene que ser aquel de la conclusión de los servicios o de la relación laboral. ${ }^{50}$ Este precepto, según la doctrina, ${ }^{51}$ infringe el artículo $19 \mathrm{~N}^{\circ} 16$ CPR en relación al $19 \mathrm{~N}^{\circ} 26$; a normas legales protectoras del derecho laboral que se basan en otras garantías constitucionales, no específicamente laborales, como el artículo $19 \mathrm{~N}^{\circ} 1 \mathrm{CPR}$; por último, de acuerdo al $19 \mathrm{~N}^{\circ} 24$-por ser los derechos regidos por el CT y las horas extraordinarias derechos adquiridos- existe propiedad sobre ellos, por lo que no poder ejercerlos dentro de la relación laboral además constituye un abuso del derecho.

En suma, devendría en inaplicable este precepto en cuanto a la forma de contar el tiempo desde exigibles los derechos; también en su inciso quinto por negar el beneficio de la suspensión de la prescripción durante la relación laboral y por convertir a la interrupción civil en una institución que -basada en la notificación válida de la demanda- producirá efectos contrarios a la protección del trabajo.

\section{UNA SOLUCIÓN DE LEGE FERENDA EN LA GESTIÓN ADMINISTRATIVA}

En este apartado propongo teóricamente modificar el CT sobre la base de una fórmula utilizada en otros países, consistente en otorgarle un efecto interruptivo civil a la

${ }^{50}$ Precisamente incompatible con el del artículo 2514 del CC. Piénsese que cuando el Código Civil adopta un criterio diverso en la forma de computar un plazo ocurren consecuencias funestas. Baste recordar cómo en el caso de su artículo 1880 la acción puede nacer prescrita.

${ }^{51}$ Cfr. Gamonal, S., Introducción al derecho del trabajo, Editorial Jurídica ConoSur, primera edición, Santiago, 1998, pp. 192-196. Este mismo autor se refiere a una sentencia del Tribunal Constitucional italiano, "la que falló estableciendo que el plazo de prescripción laboral no corre mientras se encuentre pendiente la relación laboral, a pesar de existir normas de derecho común que expresamente regulaban dicha materia. Se trata de la sentencia $N^{\circ} 63$ de 1966, que se fundó en el hecho de que el miedo al despido puede forzar al trabajador a renunciar a parte de sus derechos, y que la renuncia durante la relación laboral no puede ser considerada como la libre expresión de la voluntad negocial del trabajador”. Gamonal, S., loc. cit., p. 193. 
notificación de un requerimiento extrajudicial, ${ }^{52}$ como es el reclamo ante la Inspección del Trabajo, atendidas las circunstancias que paso a exponer.

En general, como es sabido, puede decirse que sobre la Inspección del Trabajo ${ }^{53}$ pesa una función de fiscalización del cumplimiento de la normativa laboral. Dicha labor también es ejercida por los tribunales de justicia, por lo que el modelo presenta como rasgos fundamentales ser de carácter general y de concurrencia coordinada. ${ }^{54}$ Quienes personifican esta fiscalización -los inspectores del trabajo- gozan de una serie de atribuciones para llevar a efecto esta función, sin embargo, sólo me interesa resaltar la instancia conciliativa del artículo 29 y 30 del DFL 2 de $1967 .{ }^{55}$ En virtud de tales normas, en la práctica, una vez recibido un reclamo del trabajador, la Inspección le asigna un número de anexo, fija fecha para un comparendo de conciliación y cita $^{56}$ al empleador a una audiencia para tal efecto, bajo apremio de multas duras en caso de inasistencia. En dicha oportunidad, la Inspección puede ejercer, de acuerdo al artículo 31, su atribución de requerir toda la documentación y antecedentes al empleador a fin de fiscalizar y/o acercar a las partes a algún acuerdo. Nada obsta a que el trabajador se salte la etapa administrativa y demande

52 V. gr., la Ley Federal del Trabajo mexicana dispone en su artículo 521 I: "La prescripción se interrumpe:

I. Por la sola presentación de la demanda o de cualquiera promoción ante la Junta de Conciliación o ante la de Conciliación y Arbitraje, independientemente de la fecha de la notificación. No es obstáculo para la interrupción que la Junta sea incompetente". El Código Sustantivo del Trabajo colombiano es más dúctil aún; su artículo 489 reza: "Interrupción de la prescripción. El simple reclamo escrito del trabajador, recibido por el patrono, acerca de un derecho debidamente determinado, interrumpe la prescripción por una sola vez, la cual principia a contarse de nuevo a partir del reclamo y por un lapso igual al señalado para la prescripción correspondiente". Similar caso ocurre con el artículo 257 de la Ley de Contrato de Trabajo argentina $\mathrm{N}^{\circ} 20.744$.

${ }^{53}$ En adelante Inspección.

${ }^{54}$ Ugarte explica al respecto: "Es un modelo general porque la competencia de la inspección del trabajo abarca toda la normativa laboral contenida en el Código del Trabajo y leyes complementarias, salvo contadas excepciones, casos estos últimos en que la competencia es exclusivamente judicial (...). Pero además de general, es un modelo donde la concurrencia administrativa y judicial en el conocimiento de la aplicación de las normas laborales se encuentra articulada de modo sucesivo: la actuación administrativa precede a la actuación judicial. En ese sentido, las actuaciones de fiscalización de la inspección del trabajo son revisables por los tribunales de justicia". Ugarte, J.L., "Inspección del Trabajo en Chile: Vicisitudes y desafíos", en Revista Latinoamericana de Derecho Social, núm. 6, enero-junio de 2008, pp. 188-189.

55 Ley Orgánica de la Dirección del Trabajo de 30 de mayo de 1967. Según su artículo 29, "La Dirección del Trabajo y los funcionarios de su dependencia podrán citar a empleadores, trabajadores, directores de sindicatos o a los representantes de unos u otros, o cualquiera persona en relación con problemas de su dependencia, para los efectos de procurar solución a los asuntos que se le someten en el ejercicio de sus respectivas funciones, o que deriven del cumplimiento de disposiciones legales o reglamentarias, como asimismo, para prevenir posibles conflictos.

La comparecencia deberá ser personal o por intermedio de mandatario o apoderado con amplias facultades otorgadas por escrito.

No obstante lo anterior, cuando se estimare indispensable, la comparecencia deberá ser exclusivamente personal, circunstancia que deberá hacerse constar en la citación respectiva”.

${ }^{56}$ Lo que significa que el empleador es debidamente notificado del reclamo administrativo en virtud de los artículos 29 y 30 del DFL 2 de 1967 por un funcionario del trabajo o por Carabineros de Chile. 
directamente ante los tribunales pero, en los hechos, la gran mayoría de las veces ocurre lo contrario por una utilidad evidente, ya que los inspectores del trabajo son ministros de fe por expreso mandato legal ${ }^{57}$ y el acta de comparendo, en caso de rebeldía del empleador o de no conciliar, constituye un instrumento de prueba abonado en cuanto a lo expuesto en él. Además, el acuerdo logrado en dicha oportunidad constituye título ejecutivo en virtud del artículo $464 \mathrm{~N}^{\circ} 4$ del CT.

De lo expuesto fluye que por esta actuación el trabajador sale de su inactividad, ergo, constituye una actitud desplegada de su parte que es suficiente para el sólo efecto de conservar su pretensión.

En nuestro país no se ha desconocido la trascendencia del antecedente previo a la instancia jurisdiccional que constituye la conciliación ante la Inspección y la descompresión al sistema que ella importa. Con buenas intenciones, alguna vez se quiso plasmar por la clase política un efecto interruptivo al reclamo administrativo, ${ }^{58}$ pero debido a un mayor o menor desconocimiento de las nociones de caducidad o perención, suspensión e interrupción, finalmente se estableció en el artículo 480 inciso final del CT (actual 510) que la interposición de un reclamo debidamente notificado más la concurrencia de ciertos requisitos de identidad de la pretensión, constituye una causa especial de suspensión de prescripción mientras dure el trámite del reclamo.

57 Artículo 23 DFL 2 de 1967: "Los Inspectores del Trabajo tendrán el carácter de ministros de fe respecto de todas las actuaciones que realicen en el ejercicio de sus funciones, dentro de las cuales podrán tomar declaraciones bajo juramento.

En consecuencia, los hechos constatados por los Inspectores del Trabajo y de los cuales deban informar de oficio o a requerimiento, constituirán presunción legal de veracidad para todos los efectos legales, incluso para los efectos de la prueba judicial".

${ }^{58}$ Me refiero al Mensaje del Ejecutivo $\mathrm{N}^{\circ} 451-330$ de 21 de marzo de 1995, que tuvo por objeto modificar el artículo 168 y 480 del CT, la Ley $\mathrm{N}^{\circ} 17.322$-sobre cobranza judicial de imposiciones- y una serie de artículos del CT para agilizar la tramitación en las causas laborales. Palabras textuales de la iniciativa: "En materia de prescripción y caducidad, se persigue el doble propósito, por una parte, de establecer una mayor vinculación entre los reclamos laborales que se efectúan ante la instancia administrativa y el orden judicial y, por otra, facilitar la conciliación de aquellas causas laborales que no necesariamente requieren llegar a un procedimiento adversarial. Actualmente, por la necesidad que impone el transcurso de los plazos de prescripción, se entablan paralelamente reclamos ante las Inspecciones del Trabajo y ante los Juzgados Laborales. De tal forma, se establece que la interposición del reclamo administrativo ante la Inspección del Trabajo respectiva, en el caso en que exista clara identidad de la pretensión, interrumpirá la prescripción. Ello contribuirá además, eficazmente, a aliviar la carga de trabajo de la instancia jurisdiccional". Originalmente, se contemplaba interrumpir la prescripción con la interposición del reclamo administrativo, pero la Cámara de Diputados, en segundo trámite constitucional, modificó el proyecto aprobado por el Senado, explicitando que se requiere que el reclamo administrativo ante la Inspección del Trabajo esté debidamente notificado, y reemplazando el efecto de interrupción de la prescripción por el de suspensión de la misma. Consecuencialmente, se dispuso que el plazo de la prescripción seguirá corriendo concluido que sea el trámite ante dicha Inspección, pero, manteniendo la norma de que, en ningún caso, podrá exceder de un año contado desde el término de los servicios. La razón por la cual se sustituyó la interrupción por la suspensión fue solamente evitar que se pierda el tiempo transcurrido con anterioridad a la interposición del reclamo, sin que hubiera mayor reflexión sobre los alcances de una u otra institución. 
Por otro lado, el CT, además de tratar la prescripción en el artículo 510, regula la caducidad laboral principalmente en el artículo $168 .{ }^{59}$ Respecto de ambas instituciones, la ley, utilizando un criterio pro operario, ha excepcionado una de sus características básicas, esto es, que no admiten suspensión. ${ }^{60} \mathrm{La}$ confusión que ha imperado en los operadores jurídicos con estas nociones ha sido advertida por autores franceses: "Los únicos plazos perentorios que corren el riesgo de ser confundidos con las prescripciones extintivas son evidentemente aquellos que se refieren al ejercicio de una acción judicial". ${ }^{1}$ Por eso considero que para el cabal entendimiento de la caducidad laboral, conviene distinguir sus rasgos sustantivos y procesales. Desde ambos puntos de vista, las palabras de Josserand son demasiado claras: "es de presumir que después de cierto tiempo una obligación haya sido ejecutada, o de una manera más general, que el deudor haya sido regularmente liberado; la prescripción no es sino la consagración jurídica y oficial de dicha probabilidad; es un medio de prueba o, más bien, una dispensa de prueba, tanto o más que un medio de extinción. Es muy diferente la significación de los plazos prefijados; al establecerlos, el legislador lo único lo que quiere es obligar al titular de un derecho a tomar partido rápidamente; no se hace en modo alguno intérprete de su voluntad, sino que realiza un acto de autoridad; no instituye una presunción, sino una pérdida que inflige al retardatario, pura y simplemente, y que tiene el valor de una sanción, como aquella en que incurre el estudiante que no se ha matriculado en los plazos reglamentarios". Continúa este autor: "los plazos prefijados funcionan como una guillotina, sin tener en cuenta ninguna consideración, y ello porque son completamente extraños a toda idea de prueba y de presunción; instituyen una realidad, no consagran un cálculo de probabilidades: van directamente al fin sin que nada pueda hacer que se desvíen; son verdaderas medidas de policía jurídica, libres de toda aleación”. ${ }^{62}$ De ahí que el rol

${ }^{59}$ Sin perjuicio, existen otras normas que se refieren a ella, v. gr., artículos 201, 207 y 169 a 171.

${ }^{60}$ De acuerdo al artículo 168 inciso primero, en todos los casos calificables como despido indebido o injustificado que indica la norma, el trabajador "podrá recurrir al juzgado competente, dentro del plazo de sesenta días hábiles, contado desde la separación, a fin de que éste así lo declare”. Su inciso final declara: "El plazo contemplado en el inciso primero se suspenderá cuando, dentro de éste, el trabajador interponga un reclamo por cualquiera de las causales indicadas, ante la Inspección del Trabajo respectiva. Dicho plazo seguirá corriendo una vez concluido dicho trámite ante dicha Inspección. No obstante lo anterior, en ningún caso podrá recurrirse al tribunal transcurridos noventa días hábiles desde la separación del trabajador". Por su parte, en materia de prescripción, mantiene el artículo 510 inciso final: "Con todo, la interposición de un reclamo administrativo debidamente notificado ante la Inspección del Trabajo respectiva, dentro de los plazos indicados en los incisos primero, segundo, tercero y cuarto, suspenderá también la prescripción cuando la pretensión manifestada en dicho reclamo sea igual a la que se deduzca en la acción judicial correspondiente, emane de los mismos hechos y esté referida a las mismas personas. En estos casos, el plazo de prescripción seguirá corriendo concluido que sea el trámite ante dicha inspección y en ningún caso podrá exceder de un año contado desde la separación de los servicios". (Cursivas nuestras). La preposición "ante" que utiliza la primera parte del inciso es poco feliz, ya que quien notifica de la interposición de un reclamo es la Inspección, por lo tanto, debería ocuparse la preposición "por", a fin de evitar confusiones.

${ }^{61}$ Mazeaud: Henri, Léon y Jean, Lecciones de derecho civil, parte segunda, vol. III, Ediciones Jurídicas Europa-América, primera edición, Buenos Aires, 1960, p. 414.

${ }^{62}$ Josserand, L., Teoría general de las obligaciones, op. cit., pp. 603-605. 
del juez sea limitarse a comprobar su advenimiento, debiendo declarar la caducidad de oficio, no admitiendo, en consecuencia, ni suspensión ni interrupción. Pero como el CT acepta expresamente la suspensión de la caducidad, también se ha dicho por la jurisprudencia que ella se interrumpe ${ }^{63}$ con la sola presentación de la demanda, lo que no es correcto: no siendo posible este fenómeno, el CT no refiere en ninguna parte a la interrupción de la caducidad. Lo que ocurre con ella es que con el ingreso o interposición de la demanda el trabajador cumple con una carga procesal temporal que le impone la ley por una cuestión de seguridad jurídica; con un requisito de admisibilidad ex ante para que el juez conozca y falle su pretensión.

Establecida, en consecuencia, la circunstancia de que la caducidad y la prescripción (aunque vinculadas) responden a cuestiones diversas, moviéndonos en el plano de esta última, y como es de toda lógica, ocurre que un mismo acontecimiento -como es la notificación del reclamo administrativo- no puede servir, por una parte, a fin de suspender, paralizar el tiempo que corría contra el trabajador, para retomarlo luego de cesada cierta circunstancia por la cual la ley prefiere que no corra en su contra ${ }^{64} y$, por otra, para dejarlo íntegramente sin efecto, interrumpirlo, de forma que deba iniciarse nuevamente su cómputo. He aquí el problema que surge a la luz del artículo 510 inciso final del CT.

De lege ferenda, la solución más práctica consistiría en revisar el CT y mantener el derecho optativo del trabajador de reclamar ante la Inspección en caso que considere injustificado su despido o de accionar directamente ante el tribunal. Si opta por lo primero, la prescripción se interrumpe con la notificación del reclamo al empleador, siempre que haya triple identidad entre el reclamo administrativo y la ulterior pretensión judicial. Nada más justo que así sea, si constituye una manifestación expresa de salir de inactividad. Se exige, eso sí, notificación del reclamo porque de otro modo el empleador no tiene cómo saber que se ha iniciado la gestión. ${ }^{65} \mathrm{Y}$ esa notificación, debidamente practicada, ${ }^{66}$ respeta a su favor el principio contradictorio presente en este procedimiento. ${ }^{67} \mathrm{Si}$ el

${ }^{63}$ RDJ., T. CI, Sec. $3^{\text {a }}$, considerando octavo, pp. 143-144.

${ }^{64}$ Esto es, durante la tramitación administrativa del reclamo, beneficiando al trabajador para que no le siga en el intertanto corriendo el plazo de prescripción de su acción, evitando así la tramitación paralela administrativa y judicial. Mas puede colegirse que esta suspensión juega también a favor del Estado como mecanismo de racionalización de actividades.

65 Vid. nota núm. 17.

66 Vid. nota núm. 56.

${ }^{67}$ Se debe aceptar que con esta postura quedaría sin aplicación práctica el fenómeno de la interversión, esto es, el nuevo cómputo del lapso de tiempo luego de interrumpido, transformado en prescripción de largo tiempo. Ello puede ser así, ya que si se entiende interrumpida civilmente la prescripción con la notificación del reclamo por la Inspección, comenzará a correr de nuevo el tiempo, y como el trabajador -en caso de inasistencia del empleador al comparendo administrativo o de no llegar a acuerdo- se apresurará en concurrir al tribunal para cumplir con la carga de la caducidad, entonces la nueva prescripción de largo tiempo quedará interrumpida con la acción judicial interpuesta. Si el trabajador opta por demandar directamente en sede jurisdiccional, la interversión no puede ser posible, porque la secuela del juicio terminará con una sentencia firme a favor del trabajador (restando sólo ejecutarla) o a favor del empleador, quedando absuelto. En ambos casos no puede haber otra prescripción que corra. Cfr. Domínguez, R., La prescripción extintiva. Doctrina y jurisprudencia, op. cit., pp. 352-353. 
trabajador opta por entablar directamente la demanda ante el tribunal, la interrupción civil se produce con la presentación del libelo o su ingreso a distribución, por todo lo ya manifestado, y teniendo especialmente a la vista los efectos que produce el comparendo administrativo en el empleador ${ }^{68}$ y la distinción entre caducidad y prescripción en relación al hecho del ingreso o interposición de la demanda, según señalé.

\section{Conclusiones}

Las vacilaciones hermenéuticas del artículo 2523 del CC y su pretendida unificación por la CS -en su aplicación laboral- pueden producir resultados poco felices en el trabajador, albures que a partir de la norma no resulta justificado soportar. Esta situación ha sido advertida por algunas Cortes de Apelaciones y, por lo mismo, el argumento de la Corte Suprema que llamo protección-abuso, esto es, que en base al requerimiento, la interrupción civil se produce con la notificación válida de la demanda porque el trabajador no puede ampararse en el carácter tutelar de la norma laboral excusándose de dar curso progresivo a los autos, es un argumento que, más allá de ser muy criticable en razón de las reflexiones hechas a lo largo de este trabajo, debe comenzar a ser superado si se piensa en el principio de la oficialidad y gratuidad que rige a la nueva justicia del trabajo, cuya transición quedará concluida en todo el país con fecha 30 de octubre de 2009. Por esta razón, pueden esperarse nuevos aires en el tratamiento de las normas del CT que dicen relación con el transcurso del tiempo a partir de la nueva fundamentación de la sentencia laboral.

En el ámbito anterior, si se mantiene la redacción del artículo 510 inciso quinto del CT, la alternativa de la distinción entre los efectos substantivos y adjetivos de la demanda es una solución que el juez puede fundar en la sentencia en base al subprincipio in dubio pro operario, mientras que la fórmula propuesta en la gestión administrativa requiere de una cirugía al CT, toda vez que con la notificación del reclamo administrativo el legislador contempla la suspensión de la prescripción.

Sin embargo, creo que no resultaría antojadiza una revisión del artículo 510 del CT, con mayor razón si se considera que la norma consagra algunas hipótesis en que el tiempo de prescripción se cuenta desde que se hicieron exigibles los derechos, cuestión que estando vigente la relación laboral, los haría inoperables en la realidad. Esta revisión legislativa tendría que estar enfocada a replantear el fenómeno de la suspensión y la interrupción en los siguientes sentidos: proteger al trabajador mediante la suspensión de la prescripción en todos aquellos casos en que el tiempo se cuente desde exigible la obligación o, mejor aún, establecer lisa y llanamente que todo tipo de lapso se cuenta desde concluidos los servicios o relación laboral. Respecto de la interrupción, eliminar la causal especial de suspensión del artículo 510 inciso final y establecer que la notificación

\footnotetext{
${ }^{68}$ Vid. nota núm. 37.
} 
del reclamo administrativo interrumpe la prescripción, situación que teóricamente es bastante más favorable, ya que no se retoma un período de tiempo anterior transcurrido, sino que se borra y comienza a correr uno nuevo (interversión), fenómeno este último, eso sí, que en los hechos parece quedar limitado. ${ }^{69}$

Con todo, volviendo a los inicios del siglo XX, cualquier tipo de análisis debe comenzar por reconocer una profunda diferencia entre el télos de la norma laboral y la civil y, en este sentido, resulta peligroso -según quedó demostrado- continuar con el reenvío de la interrupción civil de la prescripción liberatoria laboral al requerimiento del artículo $2523 \mathrm{~N}^{\circ} 2$ del CC, voz de discutible sentido y alcance y de la cual pende la eficacia de una pretensión judicial que envuelve derechos que legítimamente buscan ser reconocidos.

\section{BIBLIOGRAFÍA}

Alessandri, A.; Somarriva, M.; Vodanovic, A., Tratado de las obligaciones, vol. III, Editorial Jurídica de Chile, segunda edición, Santiago, 2004.

AmaYA, A., "El principio pro homine: Interpretación extensiva vs. el consentimiento del Estado", en International Law: Revista colombiana de Derecho Internacional, Pontificia Universidad Javeriana, Bogotá, núm. 5, junio de 2005, pp. 337-380. http://www.javeriana.edu.co/Facultades/C_ Juridicas/pub_rev/int_ediciones.htm [Fecha de revisión: 7 de agosto de 2009].

Cabanellas, G., Tratado de derecho laboral, vols. I y II, Editorial Claridad S.A., Buenos Aires, 1988.

Camiruaga, J.R., De las notificaciones, Editorial Jurídica de Chile, tercera edición, Santiago, 1991.

Diccionario de la lengua Española de la Real Academia Española, Tomo IX, Editorial Espasa, vigésima segunda edición, Madrid, 2001.

Domínguez, R., La prescripción extintiva. Doctrina y jurisprudencia, Editorial Jurídica de Chile, primera edición, Santiago, 2004.

Dworkin, R., Los derechos en serio, Editorial Ariel, segunda edición, Barcelona, 1988.

Gamonal, S., Fundamentos de derecho laboral, Legal-Publishing Chile, primera edición, Santiago, 2008

Gamonal, S., Introducción al derecho del trabajo, Editorial ConoSur, primera edición, Santiago, 1998

Josserand, L., Teoría general de las obligaciones, Editorial Parlamento, Santiago, 2008.

Mazeaud: Henri, Léon y Jean, Lecciones de derecho civil, parte segunda, vol. III, Ediciones Jurídicas Europa-América, primera edición, Buenos Aires, 1960.

Peñailillo, D., Los bienes, la propiedad y otros derechos reales, Editorial Jurídica de Chile, primera edición, Santiago, 2006.

SÁEz, F.; Melis, C., Derecho del trabajo, Tomo I, Editorial ConoSur, Santiago, 2000.

Ugarte, J.L., "Inspección del Trabajo en Chile: Vicisitudes y desafíos", en Revista Latinoamericana de Derecho Social, núm. 6, enero-junio de 2008, pp. 187-204. 


\section{Jurisprudencia.}

1. Corte Suprema:

- Sentencia de 27 de septiembre de 2004, recaída en causa rol 3745-03, disponible en RDJ., T. CI., Sec. $3^{\text {a }}$, julio-diciembre de 2004, pp. 142-144.

- Sentencia de 20 de enero de 2005, recaída en causa rol 5503-2003, disponible en RDJ., T. CII, Sec. 2a, enero-junio 2005, pp. 281-284.

2. Segunda Instancia:

- Sentencia de la Corte de Apelaciones de Santiago de 10 de noviembre de 2005, recaída en causa rol 973-2005, disponible en Leyes y Sentencias, Editorial Punto Lex, $\mathrm{N}^{\circ} 5$, noviembrediciembre de 2005, pp. 84-87.

- Sentencia de la Corte de Apelaciones de Antofagasta de 29 de junio de 2007, recaída en causa rol 95-2007, disponible en Leyes y Sentencias, Editorial Punto Lex, $\mathrm{N}^{\circ} 43$, julio de 2007, pp. 95-98.

- Sentencia de la Corte de Apelaciones de Santiago de 8 de enero de 2008, recaída en causa rol 2327-07, disponible en Leyes y Sentencias, Editorial Punto Lex, $\mathrm{N}^{\circ}$ 56, enero de 2008, pp. 53-54. 
